\title{
Multiple Discount Rates for Evaluating Public Forestry Investments
}

\author{
Bennett B. Foster \\ Professor of Forestry \\ Institute of Natural and Environmental Resources \\ University of New Hampshire
}

\begin{abstract}
The critical nature of the discount rate in public forestry investment evaluation is generally recognized, as is the philosophical conflict between the need for a high rate which reflects current economic and social realities, and a low rate which assures permanence and the attainment of long-term social welfare goals. Others have suggested a dual rate approach for solving this issue. The rationale leading to their dual-rate concept can be expanded into a multiple-rate concept. In addition, empirical evidence supports a multiple rate concept: one in which rates would be influenced by the duration of investment and approximated by a formula-based continuum or a multiple-step schedule. No attempt is made to set specific rates; however, there is evidence that rates above $8 \%$ are reasonable for only a decade or two, rates above $5 \%$ reasonable for durations up to approximately 50 years, and lower rates being reasonable for longer durations.
\end{abstract}

\section{Résumé}

On admet que le taux d'escompte est sujet à discussion lors de la détermination d'un investissement public en foresterie parce qu'il y a conflit philosophique entre la nécessité de fixer un taux élevé qui tient compte des réalités économiques et sociales de tous les jours et un taux modique qui assure la stabilité et la réalisation d'objectifs de sécurité sociale à long terme. Certains ont suggéré qu'on ait recours à un double taux pour règler ce problème. Le principe qui prévaut pour le concept d'un double taux pourrait s'appliquer à celui d'un taux multiple. De plus, il y a évidence empirique pour accepter le concept d'un taux multiple: les taux seraient déterminés par la durée de l'investissement et ajustés selon une continuité basée sur une formule ou par un barème à degrés variés. Aucun effort n'est fait pour en arriver à un taux spécifique; cependant, il semble évident que des taux au-dessus de 8 pour cent sont acceptables s'il s'agit d'une ou de deux décennies, des taux de plus de 5 pour cent sont acceptables pour des périodes allant jusqu'à environ 50 ans, et des taux moins élevés sont acceptables pour des périodes plus longues.

\section{Introduction}

Manning's (1977) support of Teeguarden's (1976) suggestion that public forestry investments be evaluated with a combination of two discount rates, one for "strategic long-range investment planning," and one for short-range "depletion of surplus old-growth stock," opens the door to the possibility of a multiple discount rate concept. Once the orthodox view of only one discount rate is questioned, it is both tempting and reasonable to expand the argument to the point of suggesting numerous, duration influenced discount rates.

Manning identifies the two major schools of thought concerning discount rates: the opportunity cost of capital school, and the social time preference school. The first holds to the general argument that because public sector investments are financed with funds taxed from potential private sector investors, they should be judged against the more financially attractive private sector investment opportunities ..., that public investments will be inefficient and lead to misallocation of resources if judged by a discount rate lower than the marginal return from investments in the private sector. The second, the social time preference school, holds to the general argument that public investments are undertaken for both current and future social benefit, and that since private sector investment opportunities strongly reflect the short time horizons of individuals (Pigou's "defective telescopic faculty"), they are not appropriate for the long view that society is obligated to have..., that a market based discount rate does not provide equitably for the future.

In suggesting the double discount rate concept, Manning and Teeguarden recognize the validities of both these arguments and combine them into a modified, double-rate policy tool. However, unless all strategic long-range investment planning, and all shortrange old-growth conversions fall into narrowly and specifically defined time spans, the question will arise as to how shorter-range strategic planning, and longer-range old-growth conversions should be handled, i.e., at what time frame does a "tactical" investment become a "strategic" investment (if needed duration is the proper criterion for defining strategic investments in the first place)? For example, would planning 40year pulpwood rotations use the same discount rate as planning 80-year sawlog rotations? Would all old-growth conversion be planned with the same discount rate, even though some of it may not be harvested for 20 or 30 years? Perhaps Manning and Teeguarden would allow one or two additional discount rates; and if so, the precedent would be set for multiple discount rates.

\section{Discount Rates vis-à-vis Time Frames}

Such a multiple discount rate concept does not lack support in the literature. A finer-toothed combing of the private sector opportunities arguments, for example, reveals that some economists (e.g., Baumol 1969, Freeman 1974, Stockfisch 1969) contend that public sector investments should be judged against the annual returns from successfully invested capital in the private sector. These, they point out, have been rather substantial (betwen 10 and 17 percent). Others (e.g. Bowden 1974, Samuelson 1973, Singer 1976) contend that private sector investment opportunities are reflected in the "going market rate" of interest, which is sensitive to national monetary policies and their effects on interest rates charged on loans by associated banks. In recent years these rates have fluctuated between 7 and $12 \%$ in the U.S. (Federal Reserve Bulletins 196574). Although no attempt has been made here to determine the average duration of these loans, it can reasonably be assumed that they exceed the one year duration of the previously mentioned "annual" returns from successfully invested capital, and perhaps they are as long as the 20 to 25 years typical of mortgage type loans. A similar combing of the social time preference arguments also reveals variation in the suggested dis- 
count rate, and, though more difficult to pin down, variation in the time frames to which these rates are associated.

The significance of this is that the two schools, after close examination, do not represent two distinct discount rates, nor two distinct time frames, but rather numerous rates and time frames. In general, the highest discount rates (10 to $17 \%$ ) are associated with the shortest time frame (one year) lower discount rates ( 7 to $12 \%$ ) with longer time frames (up to 20 or so years), and the lowest discount rates (social discount rates) with the longest time frames $(60,80,100+$ years). ${ }^{1}$

There does seem to be support for expanding Manning's and Teeguarden's dual discount rate concept into a multiple discount rate concept. Precisely what these duration related rates should be will not be addressed here; however, the results of determining the value increase rates of one empirical surrogate long-term natural resource "investment" might offer a point of reference for their possible magnitudes.

\section{The Performance Ceiling of One Historical Long-term Investment}

In an attempt to shed light on the potential upper limit of long-term value increase rates in natural resources by examining historical data, per acre value data in current market value dollars for "farm lands and buildings of the U.S." were selected (Bratkovich 1975). These data were chosen primarily because they were available. Although abundant value data exist for durations of up to 40 years (since the 1930's), what was sought were value data covering durations of up to and exceeding 100 years. This kind of information is in extremely short supply. These data, which have been reported periodically by region (Northeast, North Central, South and West) since 1850 (U.S. Bureau of the Census 1973), were utilized as both beginning and ending values of this surrogate natural resources investment.

Since the purpose of the original study was to determine a rough upper limit to compound rates of value growth in natural resources, no attempt was made to deflate the reported value figures into constant dollars, nor was concern paid to the fact that pakt of the reported values reflected additional interim capital investment. On the other hand, net annual earnings from these farm lands were interpreted as being part of the cost of operation (operators' wages), thus were not considered as legitimate additions to these values. The net result of these decisions most likely biased the resulting growth rates into higher values than would otherwise have occurred.

Starting with the value reported for 1850 (and treated as the investment cost), the compound rates describing the increases in value to every other reporting date were calculated (with each successive value treated as a terminal value), i.e., for the 10-year duration between 1850 and 1860 , the 20-year duration between 1850 and 1870 , etc...., through the 119-year duration between 1850 and 1969. Then starting again with the value reported for 1860 (as the investment cost), the same calculations were made for the value increases to every other reporting date (1860 to 1870 , 1860 to $1880, \ldots, 1860$ to 1969 ), and likewise for all other reported values. For each region, value increase

\footnotetext{
1 An additional discount rate/time frame example that could be added here is the official rate for evaluating water and related land resources development proposals in the U.S. These proposals are limited to 50 year (planning) durations, and currently (1975-76) the discount rate is $6.125 \%$ (U.S. Congress 1962 and Federal Register 1968).
}

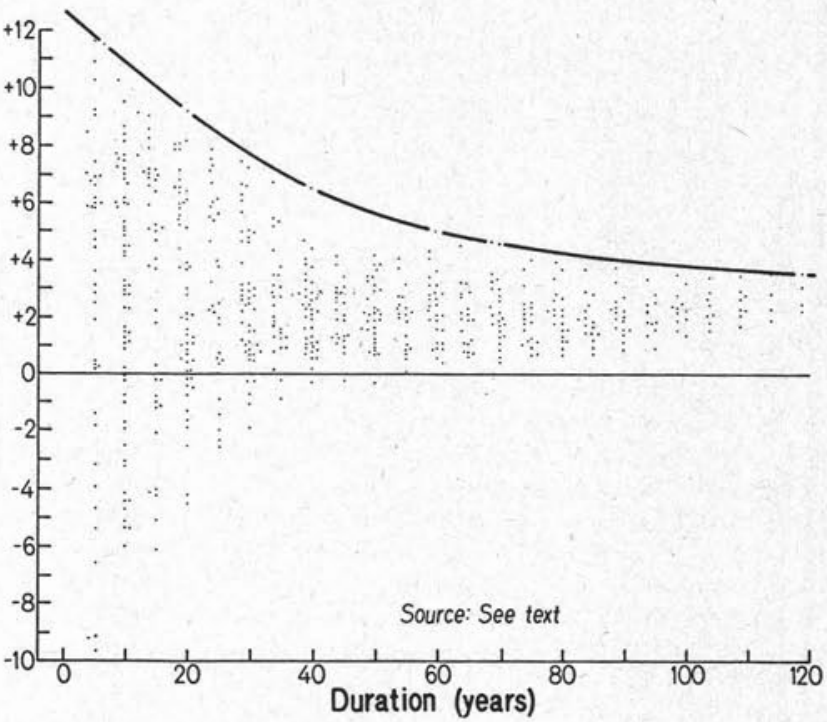

Fig. 1. Compound Rates of Value Increase of U.S. Farm Lands and Buildings (with upper bound indicated).

rates were determined for all 153 possible durations, which ranged in length from 4 to 119 years. The total 612 compound rates of value increase from all four regions were plotted over their respective durations (Figure 1). ${ }^{2}$

The resulting funnel-shaped pattern indicates that for shorter durations the compound rates of value growth varied widely, both positively and negatively. As the duration lengthens, this variability narrows, tending toward approximately 2 to $3 \%$. Even though the average rate of value growth of this investment would be approximately 2 to $3 \%$ (a regression of all points), the significance of this pattern to the issue being discussed is the shape of the upper bound. This shape indicates that the better, more attractive (upwardly biased) rates of value growth have followed a downward sloping pattern that is inversely related to duration. Similar "upper bond" slopes (and positionings) occurred when the same analytical approach was applied to the Dow-Jones common stock indices (18711970), Standard and Poor's industrial indices (1871$1970)$, and the GNP of the U.S. (1890-1970).

\section{Multiple-Step, Duration-Dependent Discount Rates}

It would be premature to suggest, without more support, that the duration related rates indicated by the upper bound of the farm lands and buildings data be used to evaluate public investments in forestry. However, a closer look at these rates might provoke some beneficial thought and discussion.

The formula that most nearly describes the upper bound in Figure 1 is:

$i_{n}=(13.71-3.38) e^{-0.0305 d}+3.38^{3}$ (equation 1)

where $\mathrm{i}_{\mathrm{n}}=$ the indicated nominal (current dollar) discount rate

$\mathrm{d}=$ the duration (years)

\footnotetext{
2 To assure understanding of this figure, the reader is urged to distinguish between the durational and the temporal aspects of time. The horizontal axis should be read as the increase in length of duration and norizontal axis should be read as the increase in length of duration and maximum annual rate of value increase of farm lands and buildings has been declining since 1850 .

3 Derived from the general formula: $i_{r}=(r o-r \infty)$ e $-k d+r \infty$ where ro $=$ initial rate, which becomes asymptotic to $r_{\infty}$ as $d$ approaches infinity.
} 
Table 1. Upper Bound Discount Rates for Selected investment Durations

\begin{tabular}{|c|c|}
\hline $\begin{array}{l}\text { Duration (d) } \\
\text { (years) }\end{array}$ & $\mathbf{i}_{\mathbf{r}}(\%)^{*}$ \\
\hline 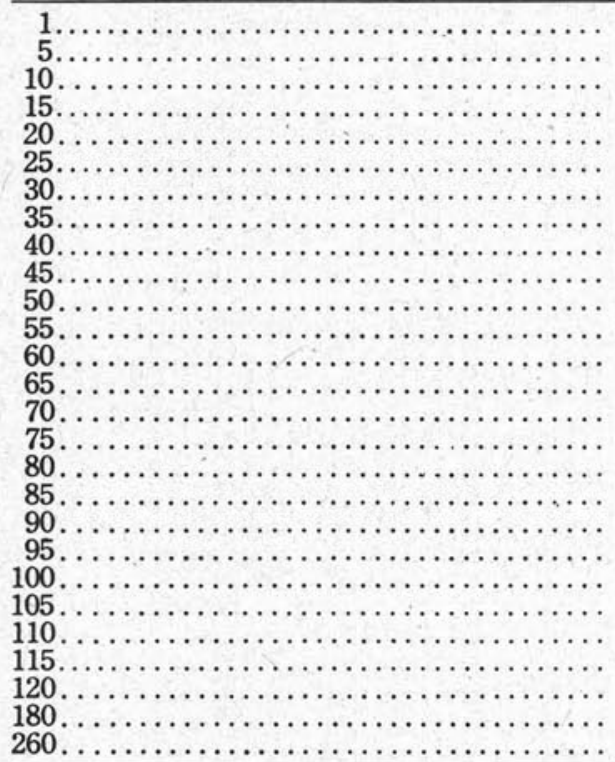 & $\begin{array}{r}12.40 \\
11.25 \\
9.99 \\
8.92 \\
7.99 \\
7.20 \\
6.52 \\
5.93 \\
5.43 \\
5.00 \\
4.63 \\
4.31 \\
4.04 \\
3.80 \\
3.60 \\
3.43 \\
3.28 \\
3.15 \\
3.04 \\
2.95 \\
2.87 \\
2.80 \\
2.74 \\
2.69 \\
2.65 \\
2.42 \\
2.38\end{array}$ \\
\hline
\end{tabular}

Source: See Text

Inasmuch as the growth rates plotted in Figure 1 are nominal rates (not adjusted for inflation), and since costs and revenues in investment evaluations are generally considered to be in real (constant) dollars, the adjusted real rate formula would be, using the $1.0 \%$ long-term inflation rate reported by the Council of Economic Advisers (1974):

$i_{r}=(10.33) e^{-0.0305 d}+2.38$ (equation II)

where $i_{r}=$ the indicated real discount rate.

Discount rates derived from this formula for selected durations are presented in Table 1.

It is interesting to note that these discount rates, in spite of the fact that they are derived from only one historical natural resource investment, track rather closely with those rates proposed in the previously cited literature. The $12.40 \%$ rate for a one-year time frame is in agreement with the 10 to $17 \%$ range proposed by Baumol (et al), the $7.99 \%$ rate for a 20 year time frame is in agreement with the 7 to $12 \%$ bank loan rates, and the 2.4 to $3.5 \%$ rates for "longterm" durations (75-plus years) are in agreement with those generally mentioned as appropriate for social discount rates. Figure 2 offers additional support for the general shape and positioning of the Farm Lands and Buildings curve. Superimposed on the upper limit curve derived from equation II are the maximum real rates of value increase of Standard and Poor's Industrials indices for selected durations, determined following the same analytical approach.

\section{Conclusion}

It is true that public forestry investment evaluation is obligated to recognize the entire continuum between long-term social/economic welfare, and the more immediate social needs and economic realities. Manning's and Teeguarden's suggestion of dual discount rates is
Compound rates of

value increase $(\%$, real $)$

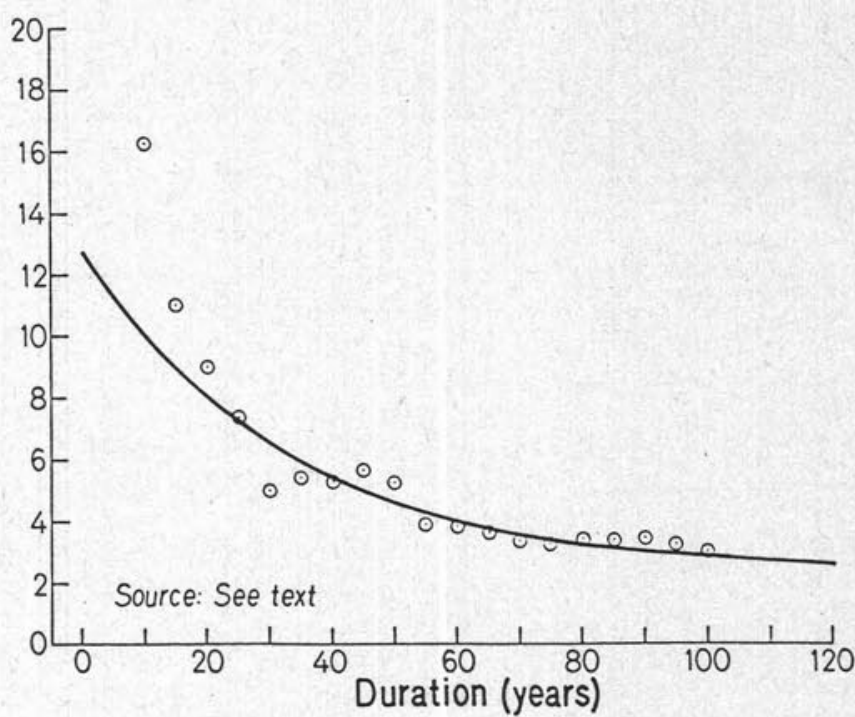

Fig. 2. Maximum Rates of Value Increase of Standard and Poor's "Industrials" Compared With Upper Limit Curve of Value Increases of Farm Lands and Buildings.

a step toward formalizing this obligation. However, if put into practice, it may reinforce the longstanding polarization of the long-term/short-term time frame conflict, and leave unrecognized the necessary and inevitable intermediate time frames. A further step toward resolving this issue would be to recognize a discount rate selection process based, in part, on a duration-related continuum, such as the formula presented here, or from a multiple-step schedule such as the one presented in Table 1.

It is generally accepted that risk, uncertainty and cost of handling are factors that influence the discount rate selection process. However, there is little evidence that investment duration has been given its rightful share of consideration. Relating discount rates to the durations of the investments being considered would be compatible with most time-related social welfare concerns, and in addition, would offer a degree of continuity to the wide range of rates currently proposed in the literature.

\section{References}

Baumol, W. J. 1969. On the appropriate discount rate for evaluation of public projects. In: Program budgeting and benefit - cost analysis. H.H. Hinrichs and G.M. Taylor (eds.) Pacific Palisades, California: Goodyear Publishing Co. Inc., pp. 202-212.

Bowden, E.V. 1974. Economics: The science of common sense. Cincinnatti: South-Western Publishing Co.

Bratkovich, S.M. 1975. The discount rate in evaluating longterm forest Investments. Unpublished MS thesis, University of New Hampshire.

Council of Economic Advisers. 1974. Economic report to the President. Washington, D.C., U.S. Gov't. Printing Office.

Federal Register, 1968. (33 F.R. 19170; 18 CRF 704.39), December, Washington, D.C.

Freeman, A.M. 1974. The benefits and costs of the DickeyLincoln project: A preliminary report, Prepared for the Natural Resources Council of Maine, Augusta.

Manning, G.H. 1977. Evaluating public forestry investments in British Columbia: The choice of discount rates. For. Chron. 53:155-158.

Samuelson, P.A. 1973. Economics: An introductory analysis, 9th edition New York: McGraw-Hill, Inc. 
Singer, N.M. 1976. Public microeconomics - An introduction to government finance, 2nd edition, Boston: Little, Brown Co.

Stockfisch, J.A. 1969. The interest rate applicable to government investment projects: In: Program budgeting and benefit - cost analysis. H.H. Hinrichs and G.M. Taylor (eds.). Pacific Palisades, California: Goodyear Publishing Co., Inc., pp. 187-201.

Teeguarden, D. 1976. Comment and viewpoints. In: McKillop, W. and W.J. Mead (eds.) Timber policy issues in British Columbia. UBC Press, Vancouver, pp. 233-239.

United States Bureau of the Census, Census of Agriculture, 1973. Farms: Number, use of land, size of farm, (Chapter
2, vol. 2, general report), Washington, D.C.: U.S. Government Printing Office, pp. 18-19.

United States Congress, 1962. Senate document 97, 87th Congress, 2nd Session; Policies, standards, and procedures in the formulation, evaluation, and review of plans for use and development of water and related land resources, Washington, D.C.

\section{Footnote}

Published as scientific contribution No. 790 New Hampshire Agricultural Experiment Station. Research Supported by Mclntire-Stennis funds.

\section{TECHNICAL EQUIPMENT SALES}

Rapidly growing supplier to the Forestry, Engineering, Geology and Surveying industries has immediate opening for Salesman in Ontario.

Experience in Technical Forestry work desired. Extensive travel throughout Ontario required.

Salary and commission commensurate with experience or abilities. Full benefit program with opportunity for fast advancement.

Please send résumé to:

Box 202, c/o Canadian Institute of Forestry

Box 5000, MACDONALD COLLEGE

Quebec HOA 1CO

Tél. (514) 457-9131

\section{CONSIDÉREZ SOUS UN JOUR RÉALISTE VOTRE RÉGIME D’ASSURANCE-VIE IFC}

Avez-vous jamais pensé à ce que le produit de votre assurance-vie IFC assurerait à votre famille, compte tenu du coût élevé de la vie aujourd'hui? Si vous n'étiez couvert que par le minimum, soit $\$ 10,000$, il est certain que votre famille n'irait pas loin.

Les membres IFC et leur famille peuvent être assurés pour $\$ 100,000$ (jusqu'à l'âge de 50 ans) à des taux de primes raisonnables. Si vous n'avez pas fait une demande d'assurance pour un montant plus élevé, il serait peut-être bon que vous songiez à reconsidérer de façon plus réaliste votre régime d'assurance-vie IFC.

L'Institut Forestier du Canada tous les détails qu'il faut.

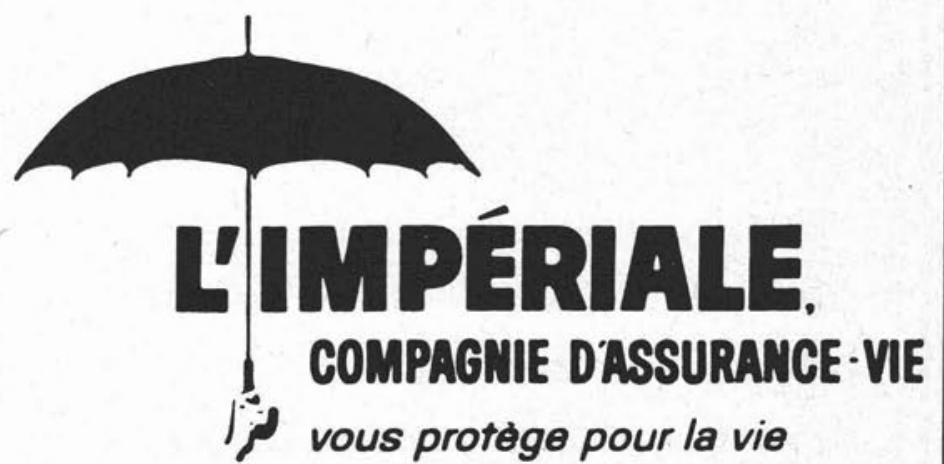

Son adresse est B.P. 5000, Collège Macdonald (Québec) HOA 1 Co 